\title{
POLITIK SEKSUAL MAJALAH HAI
}

\author{
Muria Endah Sokowati \\ Departemen Ilmu Komunikasi, Universitas Muhammadiyah Yogyakarta, JL. Lingkar \\ Selatan, Kasihan, Bantul, Yogyakarta 55183, No. Hp: 08164267335 \\ Email: muriaendah@umy.ac.id.
}

\begin{abstract}
The power or knowledge relations determine sexuality as a discourse. How understanding and practicing sex is the negotiation of knowledges and interests. It also happens in producing discourse of sexuality to adolescence. The social construction of adolescence as social category that is apolitical, hedonic, passive and uncritical brings them to be the older people's object of socialization and education about morality. Different social institutions, such as school, family, religion, government, and also media attempt to subjugate adolescense' passion in the name of sex education. This research has revealed on how the discourse of sexuality becomes arena where interests of some institutuions involved are contesting. Hai magazine is chosen as locus since this magazine has existed more than three decades and presented sex education as the material in its publication. Using Norman Fairclough's critical discourse analysis, this research has explored the discourse of sexuality as the result of negotiation of the discourse of sex sacralization brought by social and religion norms, the idea of global sexual revolution, and the perspective of health reproduction. It becomes Hai's survival strategy in economy, social and political context.
\end{abstract}

Keywords: Sexuality, discourse, adolescence

\begin{abstract}
Abstrak
Penelitian ini dilakukan untuk mengungkap berbagai kepentingan dan wacana yang turut membentuk produksi wacana seksualitas majalah Hai. Seksualitas merupakan wacana yang dibangun lewat relasi kuasa dan pengetahuan tertentu. Bagaimana seks dipahami dan dipraktekkan adalah negosiasi dari berbagai pengetahuan dan kepentingan tertentu, begitu pula dalam mewacanakan seks untuk remaja. Konstruksi sosial atas remaja sebagai kategori sosial yang apolitis, hedonis, pasif dan tidak berpikir kritis menjadikan mereka sebagai objek sosialisasi dan edukasi soal moralitas oleh orang dewasa. Penundukan hasrat atas nama pendidikan seks dilakukan oleh berbagai institusi sosial, seperti keluarga, sekolah, agama, pemerintah, dan media. Penelitian ini membongkar bagaimana produksi wacana atas seks menjadi arena bermainnya berbagai kepentingan institusi tersebut. Majalah Hai dipilih sebagai locus karena Hai adalah majalah remaja yang eksis lebih dari tiga dekade dan menghadirkan tema pendidikan seks dalam penerbitannya. Lewat metode Analisis Wacana Kritis yang dijelaskan Norman Fairclough, penelitian ini menunjukkan bahwa wacana tentang seks merupakan negosiasi berbagai wacana yang dibawa kepentingan yang berbeda, yaitu wacana sakralisasi seks yang dibawa oleh norma-norma sosial dan agama, gagasan revolusi seksual global, dan perspektif kesehatan reproduksi. Negosiasi wacana-wacana tersebut menjadi strategi Hai untuk bertahan dalam konteks ekonomi, sosial, dan politik.
\end{abstract}

Kata kunci: Seksualitas, Remaja, Wacana

\section{Pendahuluan}

Seksualitas bukan hanya persoalan erotisme, namun merujuk pada seluruh aspek kehidupan dan keberadaan manusia yang bersifat erotis seperti hasrat, praktik, hubungan dan identitas (Jackson, 2006:106). Seksualitas justru menarik perhatian remaja yang sedang dalam proses pencarian identitas. Remaja mencari informasi dari berbagai sumber seperti majalah karena tidak adanya diskusi terbuka tentang seksualitas remaja.

Konsep seksualitas mengalami pergeseran dinamis dalam majalah Hai sebagai majalah remaja. Perilaku seksual misalnya, mengalami perubahan akibat 
terbukanya informasi seks, perubahan peran gender, dan diterimanya tujuan rekreatif seks. Dalam artikel seks tahun 1990an, Hai menyebut perilaku seksual sebagai hubungan kelamin laki-laki dan perempuan setelah menikah, namun pada tahun 2000an terjadi perubahan. Majalah $H a i$ edisi 4/3/2002 mengangkat laporan utama seks di luar nikah, di mana Hai mewacanakan aktivitas seks di luar nikah adalah hal biasa di kalangan remaja.

Pergeseran wacana seksualitas laki-laki yang dibangun Hai berelasi dengan konteks sosial dan politik di Indonesia tahun 1990an dan 2000an. Pada tahun 1998 terjadi pergantian rezim pemerintahan. Transisi rezim Orde Baru ke pasca Orde Baru berimplikasi pada berubahnya ideologi gender. Penelitian ini memfokuskan majalah Hai edisi tahun 1995-2004 sebagai periode transisi.

Ideologi gender pada era Orde Baru dikontrol oleh negara. Seksualitas bukan hanya masalah individu, namun berperan sebagai reproduksi bangsa secara sosial. Seksualitas menjadi sarana pembentukan identitas nasional di mana perempuan disimbolkan sebagai penjaga utama (Yuval Davis dalam Alimi, 2004:76). Fungsi dan peran perempuan dibatasi di wilayah domestik sesuai dengan fungsi reproduksinya. Upaya itu dilakukan untuk membendung dan memanipulasi kekuatan perempuan. Negara mendefinisikan perempuan untuk melayani suami, keluarga, dan negara yang dilembagakan lewat kegiatan PKK dan Dharma Wanita. Penekanan fungsi reproduktif mendorong penyebutan ideologi gender Orde Baru sebagai ideologi state ibuism (Suryakusuma, 2011:10-11). Kategori gender disosialisasikan sedemikian rupa sehingga menjadi kodrat laki-laki dan perempuan yang tidak terbantahkan. Negara memberi legitimasi laki-laki untuk mengontrol dan mengawasi perilaku dan seksualitas perempuan (Wieringga, 2003:72).

Ideologi gender berimplikasi pada kerja media yang merefleksikan ideologi dominan dan dimunculkan dalam penggunaan bahasa. Ideologi gender ditemukan pada cara media menampilkan persoalan gender dan seksualitas. Penelitian Sen (1998) tentang femininitas dalam sinema Orde Baru menunjukkan film drama dan cerita percintaan identik sebagai film perempuan. Hal ini terkait dengan "kodrat wanita" yang ditanamkan di era Orde Baru, bahwa perempuan berfungsi sebagai ibu yang bertanggung jawab pada urusan rumah tangga. Penelitian Tomagola (1990) menyimpulkan bahwa majalah wanita menyebarkan ideologi dominan yang dianjurkan pemerintah (Suryakusuma, 1998:114).

Jatuhnya Suharto membawa perubahan konstruksi peran gender. Pemahaman ideologi gender tidak lagi terpusat pada kekuasaan negara karena muncul wacana alternatif. Penelitian Schmidt (2012) tentang representasi perempuan dalam budaya populer pasca Orde Baru menunjukkan perempuan dideskripsikan dalam dua performa: perempuan muda dan wanita karir, mandiri, ambisius dan memiliki hasrat seksual.

Iklim politik demokratis mendorong keterbukaan informasi seksualitas. Seksualitas muncul di ruang publik semenjak periode ini dan mulai menjadi komoditas. Media 
berkonten seks bermumculan sebagai sajian utama semenjak dihapusnya SIUPP. Kemunculan media franchise barat, seperti Cosmopolitan atau FHM mengakibatkan gaya dan tren barat dengan cepat diadopsi dan dikonsumsi masyarakat.

Kekuatan-kekuatan lain pada periode ini perlu dipertimbangkan dalam produksi wacana tentang gender dan seksualitas, misalnya Islam sebagai kekuatan sosial politik, dan menjadi komoditas industri budaya populer. Perkembangan teknologi media dan komunikasi juga menjadi pendorong penting perubahan sosial.

Majalah Hai sebagai produk sejarah selama lebih dari tiga dekade dipengaruhi ideologi gender yang selalu berubah. Dinamika ideologi maskulin mempengaruhi kerja redaksi majalah Hai dan tercermin dalam produksi teks seksualitas. Diskusi seksualitas juga dipengaruhi wacana yang dibawa berbagai kepentingan institusi yang terlibat dalam produksi Hai, seperti pemerintah, agama, sekolah, atau pasar. Penelitian ini dilakukan untuk mengungkap berbagai kepentingan dan wacana yang turut membentuk produksi wacana seksualitas majalah Hai.

Maskulinitas dikaitkan dengan perkembangan seksual laki-laki. Seksualitas adalah relasi laki-laki terhadap perempuan. Relasi tersebut tidak terbatas pada hal-hal fisik, tapi juga tindakan yang melibatkan kesenangan, sensasi, keintiman, rasa cinta, saling menjaga dan ketergantungan (Sprecher dan McKinney dalam Pearson, West dan Turner, 1995:8). Seksualitas mengatur peran seksual laki-laki dan perempuan.

Seksualitas merupakan konstruksi sosial. Seksualitas bukan semata-mata dorongan biologis, namun lebih ditentukan oleh proses sosialisasi yang spesifik pada waktu dan kultur tertentu (Kimmel, 2005:141). Akibatnya seksualitas menjadi cair yang selalu berubah dari satu waktu ke waktu yang lain. Sebagai konstruksi sosial, seksualitas ditentukan oleh gender. Konsep maskulinitas, definisi budaya atas manhood menentukan konstruksi seksualitas. Seksualitas dikonstruksi melalui pemahaman maskulinitas, dan melalui seksualitas identitas gender dikonfirmasi.

Seksualitas diproduksi dalam wacana. Problem relasi kuasa terjadi saat wacana dibentuk (Foucault dalam Hall, 1997: 44). Adanya dominasi dan kontrol menyebabkan tidak ada definisi tetap untuk menjawab bagaimana seksualitas. Wacana tidak pernah stabil dan bersifat situasional. Wacana seksualitas diproduksi lewat seperangkat aturan yang menentukan praktik wacana tersebut. Wacana seksualitas terikat pada sistem yang menempatkan apa yang patut dan tidak patut, benar dan salah, normal atau menyimpang yang didefinisikan lewat makna-makna yang beroperasi dalam wacana tersebut.

Wacana seksualitas beroperasi dalam sistem norma heteroseksual. Norma heteroseksual mengklasifikasikan laki-laki dan perempuan dalam relasi tertentu yang secara tegas dibedakan oleh kultur patriarki. Norma heteroseksual sebagai norma yang mengatur hubungan seksual yang melibatkan jenis kelamin yang berbeda, yaitu laki-laki dan perempuan telah menempatkan maskulinitas identik dengan kekuasaan.

Beroperasinya rezim wacana seksualitas memunculkan hegemonic male sexuality (Plummer, 2005). Apa dan bagaimana laki- 
laki ditentukan oleh penis secara fisik dan simbolis. Penis bukan semata ciri biologis laki-laki, namun simbol atas kekuatan dan dominasi laki-laki. Beberapa persoalan yang ditimbulkan oleh penis, seperti ukuran atau kemampuan dan ketahanan untuk ereksi menjadi standar seksualitas laki-laki.

Berdasarkan pandangan hegemonik, laki-laki adalah pelaku seksual aktif. Sistem patriarki melegalkan praktik dominasi lakilaki atas perempuan dan mengakibatkan relasi peran seksual yang timpang. Lakilaki berperan seksual sebagai pelaku sementara perempuan menjadi gatekeeper. Ketidaksetaraan peran seksual menghasilkan konstruksi bahwa laki-laki lebih seksual daripada perempuan. Laki-laki berupaya meningkatkan perilaku seksual untuk menunjukkan kelelakiannya, sementara perempuan harus mengontrol perasaan seksualnya jika tidak ingin dianggap hina (Kimmel, 2005:5). Konstruksi lakilaki aktif membenarkan perilaku laki-laki sebagai sexual consumer aktivitas seks, seperti pornografi, striptease, atau prostitusi (Plummer, 2005:179).

\section{Metode Penelitian}

Penelitian ini menggunakan metode analisis wacana kritis sebagai pisau analisis. Analisis teks dilakukan pada artikel dan rubrik seksualitas majalah Hai pada periode Orde Baru dan pasca Orde Baru. Fairclough (2000) menyebut wacana meliputi penggunaan bahasa dalam bentuk tulisan dan verbal, juga aktivitas semiotik yang meliputi citra visual dan bentuk-bentuk komunikasi nonverbal. Ia mengemukakan tiga dimensi analisis: teks, sebagai rekaman peristiwa dan berfungsi mengkomunikasikan fakta tertentu; praktik diskursif, tentang proses produksi dan konsumsi teks; dan praktik sosiokultural yang melihat teks sebagai bagian dari praktik sosial dan budaya tertentu.

Pada level teks dilakukan dengan melakukan analisis pada kata-kata, diksi, metafora, struktur kalimat, paradoksalitas, dan gaya bahasa. Untuk level praktik diskursif, pemahaman tentang produksi dan konsumsi teks dilakukan lewat intertekstualitas dan interdiskursivitas. Penulis melakukan analisis untuk melihat tujuan mengapa teks tertentu dipilih untuk ditampilkan. Misalnya analisis terhadap kebijakan-kebijakan redaksional majalah Hai untuk melihat relasi antara ideologi gender redaksi majalah Hai dengan produksi wacana seksualitas laki-laki dalam artikel-artikel majalah Hai. Pada level praktik sosiokultural, penulis melihat konteks sosiokultural yang melatarbelakangi produksi teks seksualitas dalam majalah Hai, misalnya analisis terhadap kebijakan pemerintah, tren media, atau isu-isu sosial yang terjadi saat produksi teks.

Penelitian ini melihat bagaimana seksualitas dipahami dan dipraktikkan dalam konteks budaya dan masyarakat yang dipengaruhi sistem sosial dan politik yang berlaku pada periode tertentu. Wacana seksualitas adalah teks yang berkaitan dengan praktik diskursif, yaitu bagaimana pemahaman ideologi gender redaksi majalah Hai; dan praktik sosiokultural, yaitu konteks sosial dan politik pada saat artikel-artikel tersebut diproduksi.

Sumber data penelitian adalah artikel dan rubrik seksualitas majalah Hai yang terbit tahun 1995-2004. Penerbitan di periode 
tersebut menggambarkan wacana seksualitas remaja laki-laki berikut kepentingan institusiinstitusi yang berkuasa pada masa itu. Topiktopik yang diteliti meliputi seks, identitas dan peran gender, orientasi seksual, erotisisme, kenikmatan, kemesraan, dan reproduksi.

\section{Hasil Penelitian dan Pembahasan}

\section{Memasarkan Seks untuk Remaja Ala Majalah} Hai.

Majalah Hai adalah satu-satunya majalah remaja laki-laki yang pernah ada di Indonesia, terbit sejak Januari 1977 dan hingga kini masih tetap eksis. Majalah remaja laki-laki menjadi strategi diferensiasi Hai dengan majalah remaja lainnya. Hal tersebut tercermin dalam tagline "cermin kehidupan remaja pria" yang menegaskan majalah Hai menjadi refleksi apa dan bagaimana menjadi remaja laki-laki. Majalah Hai menjadi referensi bagi remaja laki-laki dalam membentuk identitasnya.

Sebagai referensi remaja, Hai memasukkan konten lokal dan global sebagai strategi pemasaran dalam menjangkau pasar remaja urban. Nilan (2006) menyatakan bahwa remaja negara dunia ketiga diasosiasikan dengan nilai-nilai lokal dan global. Kultur remaja merupakan kultur hibrid antara kedua nilai tersebut, sebagai bentuk negosiasi antara identitas personal dan kelompok, dan derasnya transformasi nilai-nilai dari luar negeri (Amerika dan Eropa) yang kerap menjadi rujukan.

Upaya Hai menyeimbangkan identitas global dan lokal disebut Baulch (2002) sebagai "A Trans-national Free-ForAll'. Hai tidak selalu berkiblat pada barat, namun memposisikan konten lokal secara sejajar dengan konten global atau barat. Konten lokal dan global menghablur dan membentuk kultur hibrid. Identitas remaja dalam majalah Hai tidak bisa dilepaskan dari pengaruh identitas global dan tuntutan untuk mempertahankan identitas lokal. Hai mengajak remaja urban menyesuaikan identitas mereka dengan citra remaja barat tanpa meninggalkan budaya lokal.

Hai memposisikan dirinya sebagai rujukan gaya hidup remaja laki-laki dengan menempatkan dirinya sebagai "kakak" bagi remaja pembacanya (Satrio, Wawancara, 2014). Posisi kakak merupakan jalan Hai untuk memberikan nasehat seputar gaya hidup remaja tanpa menggurui. Posisi kakak menunjukkan Hai sebagai pihak dominan dan lebih tahu dibandingkan remaja pembaca yang inferior, sehingga harus diasuh dan dididik, inilah implementasi dari filosofi Hai sebagai "Hibur, Asuh, dan Ilmu".

Posisi kakak dimaksudkan untuk menjembatani remaja dan generasi yang lebih tua. Hai menawarkan kebebasan dari aturan kaku budaya orang tua tanpa disalahkan orang tua. Dalam menyampaikan informasi, Hai merujuk koridor norma sosial dan agama. Hai mengakomodasi kebutuhan remaja dengan tetap memahami keinginan orang tua. Identitas yang terdapat dalam artikel Hai adalah bentuk negosiasi kebutuhan dan selera remaja dan orang tua. Strategi Hai untuk menjangkau remaja tanpa berlawanan dengan orang tua adalah dengan cara berada di antara remaja dan orang tua, mengingat keputusan membeli masih dipengaruhi orang tua. 
Sejalan dengan Handajani (2010: 240) yang mengatakan bahwa majalah Hai merupakan ruang bagi remaja untuk menjadi seperti laki-laki dewasa. Hai mengadopsi nilai-nilai manhood yang dikonstruksi majalah gaya hidup laki-laki dewasa ke dalam versi remaja. Handajani menyebut konstruksi manhood dalam majalah lakilaki dewasa dengan istilah middle class "parents" culture. Ini adalah strategi Hai menyelaraskan kebutuhan remaja dan orang dewasa atau orang tua.

Berbincang tentang seks pada remaja tanpa polemik dilakukan lewat pendidikan seks. Pendidikan seks dianggap penting karena usia remaja adalah fase berkembangnya organ-organ seksual. Akibatnya remaja sudah memiliki hasrat seksual padahal menurut seksualitas prokreatif hubungan seks hanya boleh dilakukan laki-laki dan perempuan yang terikat perkawinan. UU No. 1/1975 tentang Perkawinan yang menentukan batas usia menikah, bagi laki-laki 19 tahun dan perempuan 16 tahun menyebabkan remaja belum bisa menikah dan merealisasikan hasrat seksualnya.

Gap antara hasrat dan realisasi seksual mendorong Hai dalam artikel-artikelnya menyebut istilah "masa tunggu" bagi remaja. Di satu sisi organ reproduksinya sudah bisa berfungsi, namun menurut norma sosial dan agama hubungan seks tidak boleh dilakukan di luar perkawinan. Pada masa tunggu inilah remaja rawan melakukan tindakan-tindakan yang dianggap melanggar norma sosial dan norma agama, yaitu melakukan seks bebas.

Konstruksi remaja yang apolitis dan hedonis menunjukkan remaja sebagai kelompok pasif yang tidak berpikir kritis. Hal ini menjadikan mereka objek sosialisasi dan edukasi soal moralitas oleh orang dewasa. Giroux (1998) menyatakan bahwa remaja menjadi kategori yang diisi hasrat fantasi dan kepentingan dunia orang dewasa. Remaja perlu ditundukkan hasrat dan perilakunya lewat wacana-wacana yang dibuat orang dewasa, termasuk seksualitas. Remaja dilekati harapan-harapan, seperti menjadi generasi penerus bangsa, agen pembangunan dan sebagainya; dituntut menahan hasrat seksualnya. Seks bebas, kehamilan, aborsi, pornografi merupakan ancaman bagi remaja karena bisa merusak harapan-harapan orang dewasa atas remaja. Pendidikan seks dibutuhkan untuk menjadi sarana pengontrol seksualitas remaja sekaligus sebagai mengisi "masa tunggu". Melalui pendidikan seks, Hai membangun wacana seksualitas remaja yang menjelaskan perilaku seksual yang normal, sehat, ideal dan diinginkan.

Pendidikan seks dalam rubrik dan artikel seksualitas menjadi sarana Hai untuk memberi materi seksualitas secara edukatif sekaligus menghibur. Posisi kakak memberi peluang Hai untuk menanamkan wacana seksualitas pada pembaca. Konten seksualitas dimulai tahun 1990an, dilatarbelakangi banyaknya pertanyaan tentang seks dari pembaca lewat telepon. Menurut Satrio (wawancara, 2014), pembaca memiliki rasa ingin tahu tentang seksualitas, namun kesulitan untuk mendiskusikan dengan orang tua atau guru, maka pada tahun 1999 Hai mulai membuat rubrik yang membahas problem seksualitas dan berfungsi sebagai pendidikan seks bagi remaja. 
Tema-tema seksualitas yang dibahas cukup bervariasi, seperti mimpi basah, masturbasi, permasalahan seputar penis, fantasi, homoseksual, seks bebas, pornografi, cyberseks, penyakit menular seksual, penyimpangan seksual dan lain-lain. Tematema tersebut ditampilkan dalam beberapa format: artikel liputan tentang seksualitas, tanya jawab, artikel lepas tentang tema tertentu, opini selebritis atau tokoh, tulisan pakar, tips-tips, artikel tentang mitos seks, rubrik seks, kuis yang berfungsi sebagai indikator perilaku remaja yang berkaitan dengan persoalan seks, atau polling redaksi tentang tema seksual tertentu. Pembahasan dilakukan secara informatif dan edukatif oleh berbagai narasumber, seperti dokter, psikolog, sosiolog, seksolog, rohaniwan atau guru. Redaksi juga mengambil sumber dari internet, seperti: www.teengrowth.com atau Onhealth.com.

Data artikel dan rubrik seksualitas tahun 1995-2004 adalah seperti diagram 1.
Gambar 1 menunjukkan bahwa jumlah artikel dan rubrik seksualitas mengalami lonjakan drastis di tahun 1999 di saat berlangsungnya liberalisasi dan industrialisasi media yang memicu euforia kebebasan pers dan komodifikasi seks di media. Tulisan "Dari Redaksi Hai" edisi 15/10/1996 menyebutkan bahwa Hai mulai menggunakan kata "seks", setelah sebelumnya menggunakan istilah "pergaulan sehat". Kata "seks" secara eksplisit dipakai karena masalah seks ternyata membawa banyak persoalan, sehingga penting didiskusikan secara lebih terbuka. Beberapa saat setelah Orde Baru pada 1999 runtuh diikuti dengan liberalisasi pers, Hai mengikuti semangat kebebasan tersebut, termasuk dalam mendiskusikan seks.

Konten seks justru memberi hiburan bagi pembaca meskipun mengandung informasi yang edukatif. Fungsi menghibur menjadi fungsi wajib media di era liberalisasi dan industrialisasi, menggeser fungsi informatif dan edukatif. Lewat

\section{Artikel dan Rubrik Seksualitas}

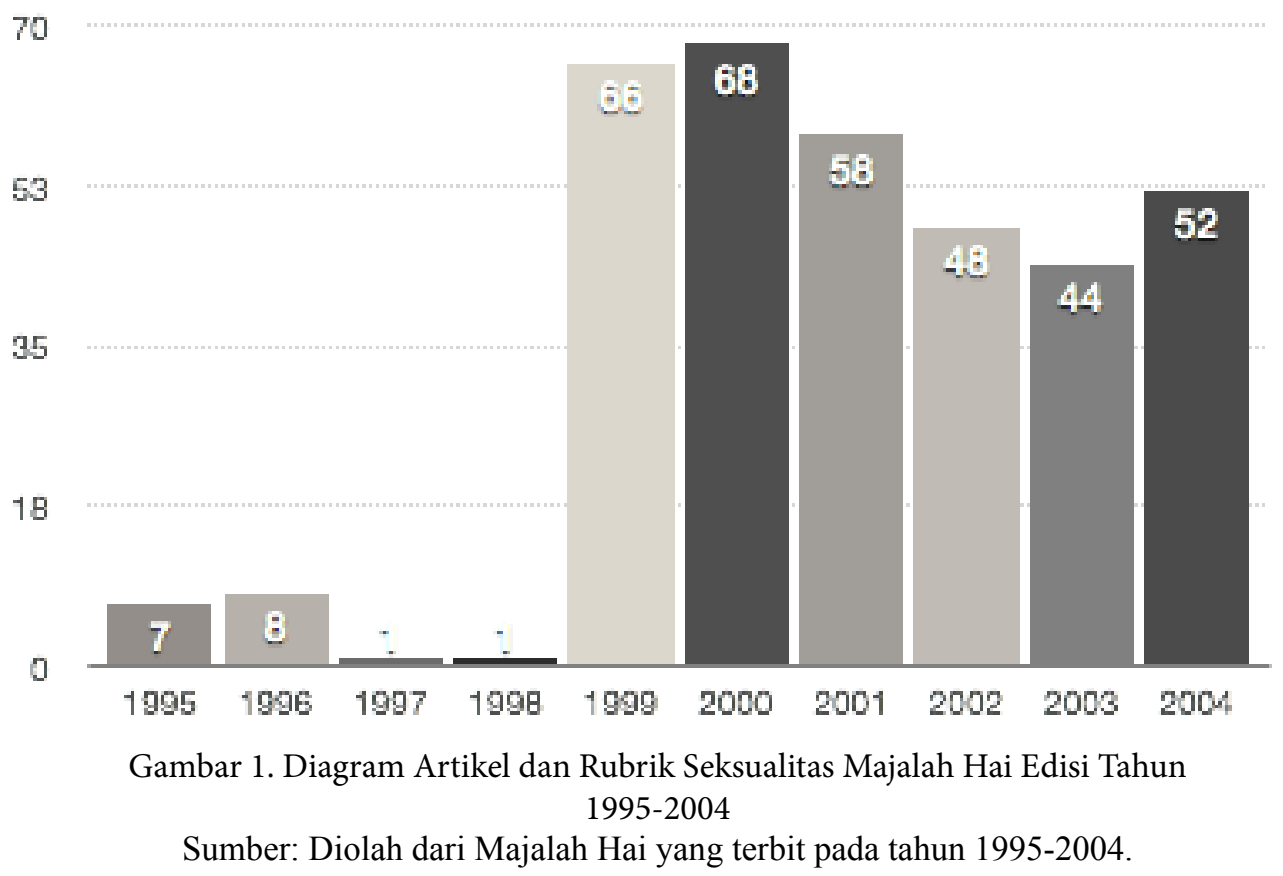


fungsi inilah media, termasuk majalah Hai, menarik minat dan perhatian khalayak. Fungsi menghibur konten seks disajikan lewat gaya bahasa humoris menggunakan istilah-istilah populer remaja. Artikel dan rubrik seksualitas disajikan dengan model lay-out halaman yang bervariasi. Ilustrasi juga lebih bervariasi, mulai dari foto, lukisan atau gambar-gambar komikal dengan ceritacerita bernada humor.

\section{Isu-Isu Kontrol, Emansipasi dan Medis dalam Konten Seksualitas.}

Tidak ada konsensus dalam pendidikan seks, masing-masing kelompok memperbincangkan hal berbeda. Institusi pendidikan memiliki kepentingan berbeda dengan institusi medis, lembaga swadaya masyarakat, agama atau industri budaya. Akibatnya masing-masing institusi memberikan perspektif berbeda dalam kurikulum pendidikan seks untuk remaja sebagai target sasaran.

Majalah Hai selaku institusi media yang menyampaikan pendidikan seks bagi remaja juga tidak terlepas dari adanya kontestasi wacana dan kepentingan dalam membangun wacana seksualitas remaja laki-laki. Materi seks disampaikan lewat berbagai perspektif, yaitu perspektif medis, psikologis, normatif dan religius. Pihak-pihak yang turut terlibat dalam menyampaikan informasi tentang seks antara lain dokter, seksolog, psikolog, guru, pakar, rohaniwan, selebritis, dan youth center dari beberapa Lembaga Swadaya Masyarakat (LSM) seperti Yayasan Centra Mitra Muda (CMM) yang mengasuh rubrik "Seks \& Drugs", atau Yayasan Pelita Ilmu (YPI). Masing-masing institusi menyampaikan gagasan seks yang mewakili wacana seksualitas normatif dan kebebasan seksual. Gerak Hai di antara dua wacana itu secara eksplisit disampaikan lewat pertanyaan berikut, "Makin banyak remaja melakukan hubungan seks tapi normanorma masyarakat kita masih bilang nggak boleh. Mau ikut yang mana?" (25/7/2000).

Konsep konservatisme seksual yaitu nilai-nilai seksual yang terinstitusionalisasi dalam kehidupan masyarakat dan dipandang sebagai pedoman dalam praktik seksual. Persoalan seksualitas dikaitkan dengan pernikahan atau relasi suami-istri, problem kesehatan, dan reproduksi. Persoalan seksualitas disebarkan lewat wacanawacana ilmiah, pengetahuan medis dan hukum. Menurut Blackwood (2007:295), seksualitas normatif di Indonesia disampaikan lewat wacana tentang keluarga, pernikahan, komunitas, dan agama. Pernikahan menjadi satu-satunya sarana dan ruang berlangsungnya aktivitas seksual sehingga seksualitas berfungsi untuk memperoleh keturunan dan membentuk keluarga. Gagasan ini didukung negara lewat berlakunya UU perkawinan sebagai legitimasi atas nilai-nilai tradisional, adat istiadat dan norma agama.

Wacana kebebasan seksual muncul seiring penerimaan perilaku seks di luar relasi heteroseksual, monogami dan pernikahan. Wacana ini dipicu meluasnya wacana kesetaraan gender dan kritik atas nilai-nilai perkawinan tradisional yang menimbulkan banyak persoalan. Globalisasi dan perkembangan teknologi komunikasi mendorong masuknya informasi kebebasan 
seksual di Indonesia. Kebebasan seksual memunculkan kekhawatiran pemerintah dan kelompok agama karena pre-marital sex, extramarital sex, homoseksual, dan industri seks komersial membawa kerusakan moral dan melawan nilai-nilai budaya dan agama. Anak-anak muda dianggap rentan terhadap pengaruh budaya global dan seksualitas yang tidak bermoral dari barat (Parker dan Nilan, 2013:22). Wacana seksualitas majalah Hai dipengaruhi pendekatan norma dan agama, fenomena revolusi seksual global, dan perspektif sains. Ketiganya menyumbangkan gagasan sakralisasi seks, seks sebagai gaya hidup dan kesehatan seksual.

\section{Sakralisasi Seks lewat Pendekatan Norma Sosial dan Agama.}

Sakralisasi seks adalah pemahaman yang memperlakukan kesucian seks sehingga harus dijaga, dieksklusifkan, dirahasiakan dan dikontrol. Di sinilah norma sosial, nilai-nilai kesusilaan, dan agama memegang peranan penting. Pendekatan norma sosial dan agama melahirkan wacana moralitas tentang seks.

Perilaku seks sejatinya tidak bermakna. Kultur yang melingkupinyalah yang membuat tindakan seksual dan orang-orang yang terlibat menjadi bermakna (Fischer, 2005:56). Makna tindakan seksual dan identitas pihak-pihak yang terlibat dibangun dalam sebuah struktur yang disebut moralitas. Serangkaian perilaku seks diberi label bermoral atau amoral, positif atau negatif. Seseorang bisa memiliki derajat moralitas lebih tinggi dari orang lain. Fischer (2005:57) menjelaskan bahwa wacana moralitas tidak hanya bertujuan mengontrol kehidupan seks seseorang, namun juga membuat klaim-klaim atas posisi moralitas individu dengan membuat stigma.

Setiap kultur memiliki standar moralitas sendiri atas tindakan seksual yang berlaku dalam waktu tertentu. Keragaman tersebut diseragamkan lewat UU Perkawinan, nilainilai tradisional, adat ketimuran, dan nilainilai agamis, pada pemahaman bahwa lembaga perkawinan menjadi satu-satunya institusi dilegalkannya hubungan seksual (Blackwood, 2007:296). Lembagaperkawinan heteroseksual menjadi standar moralitas seseorang. Sakralisasi seks dilanggengkan lewat wacana moralitas seksual.

Menurut Allen (2011) wacana moral rights dalam pendidikan seks menjadi sarana promosi ajaran religius tentang pernikahan, seksualitas dan relasi antar manusia. Konten pendidikan seks mengandung doktrindoktrin agama dan konservatif. Ide yang disampaikan adalah pengendalian diri sebagai solusi persoalan seksualitas seperti seks bebas atau aborsi yang mengancam remaja. Pendekatan ini juga menyampaikan pesan-pesan yang memfokuskan pada bahaya perilaku seks menyimpang berikut akibatnya dengan menekankan rasa takut, dan mengemukakan alasan berbasis norma sosial dan agama. Contohnya adalah seks di luar ikatan pernikahan, aborsi dan homoseksualitas adalah dosa.

Pendidikan seks pada majalah Hai menggunakan pendekatan norma sosial dan agama disampaikan oleh guru, rohaniwan, juga LSM kesehatan reproduksi remaja, yaitu CMM dan YPI. CMM secara khusus mengasuh "Rubrik Seks \& Drugs" sebagai pusat informasi dan pelayanan remaja 
tentang kesehatan reproduksi. CMM adalah program yang dibentuk Perkumpulan Keluarga Berencana Indonesia (PKBI) DKI Jakarta dan berperan sebagai pusat informasi dalam pelayanan kesehatan reproduksi remaja. YPI merupakan LSM yang peduli pada permasalahan HIV/AIDS dengan narasumber dokter dan psikolog. Kedua pihak memberikan muatan-muatan yang relevan dengan moralitas meskipun bergerak dalam bidang kesehatan reproduksi.

Dokter dan psikolog-selain memberi argumentasi ilmiah-juga menggunakan pendekatan moralitas, misalnya dalam diskusi tentang pendidikan seks di sekolah. Dr Hendrawan Nadesul, seorang praktisi kesehatan, mengemukakan alasan perlunya diskusi tersebut karena pelajar sering menjadi sorotan akibat perilaku seksual yang menyimpang. Ia merujuk beberapa kasus yang terjadi, misalnya tertangkapnya pelajar yang melakukan pesta seks di Jawa Tengah, kasus aborsi yang dilakukan pelajar, terjaringnya pelajar yang menyandang status tuna susila, dan pelajar yang ketahuan membawa buku dan video porno. Ia menggarisbawahi bahwa perilaku-perilaku tersebut sebagai perilaku menyimpang karena bertentangan dengan nilai dan norma yang berlaku (Pendidikan Seks di Sekolah: Ada, Tapi Malu-Malu, 24/2/1998).

Artikel "Penelitian Itu Membuat Panik" (14/11/1995) menjelaskan kontroversi penelitian perilaku seks di kalangan remaja yang dilakukan oleh pelajar. Tidak ada pernyataan pihak sekolah yang mendukung penelitian tersebut. Sekolah justru mengingkari hasil penelitian yang menyebutkan sejumlah pelajar telah melakukan hubungan seks pranikah. Seorang pakar statistik selaku narasumber bahkan menegaskan remaja belum pantas meneliti seks. Hal itu menunjukkan institusi pendidikan masih melihat persoalan seks sebagai hal tabu untuk didiskusikan remaja.

Institusi pendidikan menganggap penting pendidikan seks untuk menghindari perilaku seks bebas. Romo Warta, seorang rohaniwan, secara tegas menyatakan bahwa seks mengandung nilai-nilai luhur dengan fungsi reproduksi. Inilah bentuk sakralisasi seks di mana seks dipandang tabu untuk didiskusikan remaja karena seks berfungsi untuk kepentingan reproduksi dan hanya pantas dibicarakan mereka yang sudah menikah.

Pendekatan norma sosial dan agama disampaikan dalam diskusi tentang perilaku seksual. Misalnya dengan pernyataan berikut:

"Banyak yang sadar bahwa ciuman sambil tangannya ber"gerilya" adalah tindakan yang salah karena bertentangan dengan hukum agama" (Sex Dalam Pacaran: Is That The Way

We Are, 3/3/2003).

"Orang dewasa aja kalo belum menikah harusnya nggak boleh tuh yang namanya having sex. Soalnya budaya, kebiasaan, dan norma norma yang dianut di sini masih begitu ketat" (Cukup Sampai Kissing Aja, 3/3/2003).

"Cowok yang udah pernah melakukan hubungan sex, apalagi sebelum ada ikatan resmi, pasti bakal ngerasa bersalah abis-abisan! Ya ngerasa bersalah sama cewek yang ditidurinya, juga ngerasa bersalah sama ortunya. Belum lagi ngerasa dikejar- kejar dosa lantaran udah ngelanggar perintah agama" (Ketika Keperjakaan dipertanyakan 13/12/2004).

Pernyataan-pernyataan tersebut ditegaskan oleh psikolog yang .menjelaskan bahwa gaya berpacaran remaja merupakan fenomena degradasi lingkungan dan standar 
nilai. Dalam beberapa artikel disebutkan remaja perlu dilindungi dari masuknya budaya barat yang mengancam norma dan budaya ketimuran yang menganggap seks sebagai sesuatu yang sakral dan tidak pantas dibicarakan sembarangan. Masuknya budaya barat lewat perangkat teknologi dan budaya populer mendorong terjadinya degradasi moral dengan indikator semakin vulgarnya gaya berpacaran remaja. Inilah bentuk otoritas norma sosial dan agama dalam meregulasi perilaku seksual remaja.

Liberalisasi dan industrialisasi media menimbulkan kecemasan di kalangan masyarakatkelas menengah. Mereka menilai media melakukan proses westernisasi dan sekularisasi yang mengancam nilainilai agama, dalam hal ini nilali-nilai Islam (Widodo, 2008). Media mendorong terjadinya degradasi moral generasi muda yang menjauhkan mereka dari tradisi dan agama. Hal ini mendorong kelompokkelompok Islam yang memiliki posisi kuat pasca runtuhnya Suharto meregulasi seksualitas.

Nilai-nilai Islam juga mempengaruhi diskusi seksualitas terutama sejak tahun 2000, misalnya artikel-artikel yang bertepatan dengan bulan Ramadhan. Dalam rangka bulan puasa, Hai membahas pacaran atau menahan nafsu di bulan puasa. Topik tersebut didorong adanya pemahaman bahwa berpacaran dan mengumbar nafsu dapat membatalkan puasa. Hai menyatakan perlunya mengerem nafsu seksual. Pada edisi 26/11/2001, rubrik "Seks \& Drugs" mengundang ustadz Abu Ridha selaku ketua Yayasan SIDIK (Studi dan Informasi Dunia
Islam Kontemporer) sebagai narasumber. Topik yang dibahas adalah mimpi basah saat berpuasa, apakah membatalkan puasa atau tidak.

Penjelasan atas hal tersebut menggunakan perspektif agama:

Dan menurutnya, yang bisa ngebatalin puasa itu cuma tindakan-tindakan nyata yang dilakukan secara sadar, misalnya makan dan minum. Atau kalo yang menyangkut urusan esek-esek, ya melakukan kegiatan seksual. Sendirian kayak masturbasi ataupun dengan partner.

Solusi agama seperti mandi besar, berniat dan berdoa juga disampaikan:

"Biar nabirong (nafsu birahi merongrong) itu hilang, kata pak ustadz sebaiknya setelah bangun tidur cepat-cepat mandi besar. Siram kepala dari ujung rambut sampai ke ujung kaki dengan air dingin. Konon tetesan air ini bisa bikin saraf-saraf yang tadinya tegang jadi kendur. Tapi jangan lupa berniat dan berdoa. Minta kepada Tuhan supaya nafsu dihilangkan sementara," ujar ustadz Abu mengingatkan.

Tidak hanya itu, solusi agamis juga disampaikan oleh dokter di artikel yang sama, yaitu wiridan dan tadarusan untuk mengalihkan perhatian dari nafsu yang timbul.

Hal yang menarik adalah jika artikel di luar bulan puasa menyebutkan masturbasi itu aman asal tidak berlebihan, maka dalam edisi bulan puasa, masturbasi dilarang karena menyebabkan dosa, bukan sekedar membatalkan puasa (Ngerem Libido, 27/10/2003).

Pemahaman tentang seksualitas sebagai hal sakral menyebabkan adanya upaya 
untuk mengontrolnya lewat stigma terhadap perilaku-perilaku seksual tertentu yang dianggap berdosa, melanggar norma, dan melawan nilai-nilai ketimuran. Dengan melibatkan isu-isu tentang kontrol atas seks, bukan berarti Hai melarang perilaku seks, karena dalam Hai juga dipengaruhi oleh wacana kebebasan seksual.

\section{Seks dan Gaya Hidup sebagai Efek Revolusi Seksual Global.}

Revolusi seksual global adalah pergeseran konsep seksualitas, perkawinan dan keluarga di Amerika pada tahun 1960an. Pemahaman konservatif bahwa berkeluarga adalah kewajiban sehingga perceraian dianggap tidak pantas; laki-lakidanperempuanyangberkencan bertujuan untuk memperoleh pasangan hidup, bukan untuk bersenang-senang; perempuan harus menjaga keperawanannya sampai menikah; homoseksualitas dipandang haram dan ilegal; telah bertransformasi (Escoffier, 2015:1). Tidak hanya di Amerika, di Eropa juga berlangsung revolusi yang sama. Di Swedia perdebatan tentang aborsi tengah berlangsung. Gerakan-gerakan counter culture di Belanda, Inggris dan Prancis ikut mempromosikan seks bebas dan nudity (Hekma dan Giami, 2014:1).

Gerakan perempuan yang menuntut persamaan hak memperoleh kenikmatan seksual dan lepas dari jeratan moralitas konvensional menjadi faktor pendorong transformasi tersebut. Kemunculan alat kontrasepsi mengatasi kekhawatiran perempuan akan kehamilan dalam hubungan seksual. Perempuan lebih bebas mengekspresikan seksualitasnya. Akibatnya perempuan memiliki pilihan untuk melajang dan mencari kenikmatan seksual. Perempuan punya pilihan dalam mengejar kenikmatan seksual, yaitu berpasangan dengan siapapun. Keputusan atas pilihan-pilihan tersebut berdasarkan pada pertimbangan-pertimbangan rasional atas konsekuensi yang terjadi. Komitmen yang dibangun tidak terbatas pada komitmen material dan prokreasi, namun juga kesepakatan yang menguntungkan kedua belah pihak berdasarkan rasa cinta, sehingga dalam hal ini, seks dan seksualitas telah menjadi pilihan gaya hidup masyarakat moderen (Giddens, 1991).

Fenomena revolusi seksual menyebar ke berbagai negara termasuk Indonesia lewat media. Industrialisasi dan liberalisasi media turut menyebarkan gagasan kebebasan seksual. Majalah Hai pun ikut mensosialisasikan gagasan ini kepada pembaca.

Menurut Allen (2011:50), ide-ide kebebasan seksual dalam pendidikan seks mewacanakan ide seksualitas sebagai hal normal dan tidak memalukan. Seksualitas untukdinikmati,bukanditekanataudiingkari. Seksualitas merupakan pengalaman yang bebas untuk dijalankan tanpa paksaan, kekerasan atau penyalahgunaan. Gagasan ini mempromosikan kenikmatan seksual dan perbedaan seksual. Pendidikan seks mendorong remaja memiliki kemampuan menata emosi dan kehidupan sosial mereka.

Ide kebebasan seksual disampaikan selebritis yang menceritakan pengalaman seksual atau opini mereka tentang seks. Sarah Sechan dan Jamie Aditya, yang besar di negara penganut kebebasan seksual seperti Amerika dan Australia, keduanya menolak seks sebelum menikah (Your Body is Your 
Temple, 3/9/1999). Alasannya bukan soal moralitas, keduanya justru mengemukakan alasan rasional. Tidak melakukan seks bebas adalah pilihan mereka.

Setelah gede, Jamie sama sekali nggak setuju seks bebas. Buatnya dalam berhubungan itu harus ada cinta yang melandasi. Jadi nggak semata tuntutan nafsu, yang kadang bisa muncul akibat dorongan alkohol atau drugs. "Sempet juga sih, saya nyoba. Apalagi saya tinggal di Australia. Disanakan kalo udah kenal alkohol abis itu bisa langsung. Gua pemah coba, tapi nggak asik, nggak asik. You feel bad afterward," katanya.

Pilihan Jamie Aditya untuk tidak melakukan seks bebas karena ia merasa tidak nyaman. Sementara Sarah Sechan, walaupun berlatar belakang budaya barat, ia merasa budaya timur masih mempengaruhinya. Pengaruh budaya lokal dalam pengambilan keputusan relevan dengan penjelasan Giddens (1991:80) bahwa dalam menentukan pilihan gaya hidup, individu akan membenturkan nilai-nilai global dan lokal yang mempengaruhinya. Hal itu menjadi bagian dari refleksi diri masyarakat post-traditional.

Refleksi diri mendorong individu untuk menggali informasi seks dan seksualitas sebagai referensi untuk menentukan pilihan, seperti dijelaskan Edi Brokoli berikut ini:

Karena itu, Edi nggak setuju dengan one nite stand atau "jajan". "Resiko kena penyakitnya gede. Kalo lo ngelakuin itu dengan pasangan lo berarti lo nurunin risiko kena penyakit. Lagian jangan free sex banget lah. Cari yang sehat aja," paparnya. Cowok yang sibuk ngemsi dan siaran ini juga ngaku banyak baca artikel tentang cewek. Katanya sih ngebantu banget untuk tau lebih jauh anatomi tubuh cewek. Sekalian biar nggak melulu konsentrasi sama "perabotan" sendiri gitu, loh! (For The First Time, 4/3/2002).

Alasan tentang perilaku seks yang sehat juga menjadi pertimbangan.

"Godaan untuk itu pasti ada. Kapan aja, di mana aja, pasti ada. Balik lagi ke gimana orang menghadapinya. Gue nggak bisa bilang setuju atau nggak (dengan masalah premarital sex). Gue cuma bisa bilang, have safe sex. Mau sebelum atau sesudah kawin, yang penting safe sex,"jelas si gondrong ini (Eki Humania dalam Keburu Napsu, Gimana Nge-rem-nya?, 25/7/2000)."

Kebebasan seksual mendorong keterbukaan seks, termasuk mengekspresikan pengalaman seksual. Para selebritis menjelaskan pengalaman seksual mereka secara terbuka dalam artikel "For The First Time" (4/3/2002) sebagai berikut:

"Untuk hal yang satu ini Audy nganjurin untuk baca sebanyak-banyaknya supaya bisa jaga diri. Apalagi gaya pacaran remaja sekarang udah bebas banget. "Sekarang kan cipete (memakai istilahnya, alias ciuman. sama pegang te**k, Red.), ciuman dengan lidah, sampai ML itu udah biasa," tambah cewek yang ngaku cukup moderat ini. Kalo kamu sendiri? "Yah, kayak-nya sampai cipete aja, deh. Cukup sampai situ." (Audy, Penyanyi)."

Menurutnya, untuk making love nggak cukup dengan napsu aja, tetapi harus ada etikanya, mulai dari "cemilannya", menu utama, sampe afterplay. Banyak orang yang nggak merhatiin hal yang satu itu. Gue selalu berusaha untuk nggak egois. Biar udah klimaks, tapi kan pasangan gue tetep butuh penutup. kayak dipeluk gitu-lah. Makanya dalam sex itu yang namanya komunikasi penting banget," ujar penyiar MTV on Sky ini semangat (Lembu, penyiar dan vokalis band Club Eighties). 
Si Kribo ini menganggap bolehboleh aja melakukan premarital sex asal berdasarkan cinta. Dan, tanggungjawab itu penting banget. Sebaiknya pakai pengaman setiap kali berhubungan. Kalo cowok ya pake kondom. atau yang cewek minum pil. “Tapi gue sih prefer pake kondom, soalnya kita kan nggak tau efek pil itu ke tubuh cewek," jelasnya panjang lebar. Dengan semangat Edi lantas nyeritain pengalaman pertamanya. "Pertama kali ngerasain. Enak banget. Rasanya amazing." jawabnya sambil senyum-senyum. Katanya, rasanya jadi begitu hebat karena dilandasi rasa sayang sama pasangan (Edi Brokoli, presenter).

Pengalaman seks selebritis merepresentasikan seks yang nikmat. Kenikmatan seksual diperoleh jika seks berlandaskan cinta, kasih sayang, tanggung jawab dan komitmen. Pernyataan ini didukung Lola Amaria, sutradara dan pemain film:

Sama kayak Edi Kribo, menurut Lola, sex harus dilakukan dengan kasih sayang. "Gue nggak setuju dengan premarital sex. Emang sih jaman sekarang semuanya lebih terbuka, tapi yang ngelakuin harus punya tanggung jawab juga," paparnya.

Menurut Giddens (1992), kebebasan seksual yang membawa nilai-nilai kesetaraan, komitmen dan kesepakatan yang saling menguntungkan tidak terlepas dari gagasan tentang cinta. Relasi seksual berlandaskan pada keintiman yang emosional di mana pihak-pihak yang terlibat memiliki posisi setara. Penjelasan selebritis mewakili pemaparan Giddens (1992) bahwa persoalan seks adalah pilihan individu. Perilaku seks sebelum atau sesudah menikah adalah pilihan yang dilakukan secara sadar dan dilatarbelakangi hubungan emosional, atau bahasa para selebritis tersebut adalah cinta. Cinta menimbulkan tanggung jawab dan komitmen yang bersifat resiprokal.

Pemahaman seks sebagai gaya hidup yang dipilih remaja dengan komitmen, tanggung jawab dan berdasarkan cinta dan keintiman merupakan pemberdayaan remaja. Beberapa tulisan yang dikutip di atas memberi ruang refleksif bagi remaja atas tindakan seksualnya. Hai terbuka terhadap isu-isu emansipasi seksual. Emansipasi yang dimaksud bukan emansipasi seluas-luasnya, tapi dibatasi norma dan nilai konservatif.

\section{Kesehatan Seksual lewat Pendekatan Sains}

Pendekatan ini menaruh perhatian pada faktor kesehatan dalam perilaku seksual dengan membangun kesadaran praktik seksual yang sehat. Konsep pacaran sehat mengindikasikan bahwa praktik seksual meliputi kesehatan fisik psikis, dan sosial. Sehat secara fisik berarti tidak terjadi "kerusakan fisik" akibat kehamilan dan penyakit yang berhubungan dengan organ seksual. Sehat secara psikis berarti perilaku seksual tidak mengganggu jiwa pihak yang terlibat. Sedangkan sehat secara sosial berarti aktivitas pacaran tidak melanggar norma dan nilai masyarakat (Pacaran Sehat, 3/6/1999). Penjelasan tersebut dilakukan dokter, seksolog dan psikolog, juga LSM (CMM dan YPI).

Menurut Allen (2011), pendekatan health pragmatism berorientasi pada kesehatan populasi. Institusi perlu memastikan perilaku seksual yang sehat, bebas infeksi penyakit dan persoalan kesehatan seksual dengan membangun pemahaman pentingnya kesehatan seksual dan menjelaskan resiko aktivitas 
seksual. Pengetahuan ini dapat menekan jumlah penderita penyakit menular seksual dan penyakit reproduksi lain di kalangan remaja. Pendekatan kesehatan menyediakan informasi seks yang sehat dan penggunaan kondom sebagai pencegah penyakit menular seksual.

Allen (2011:49) menegaskan wacana kesehatan mengadvokasi konten-konten pendidikan seksual yang berdasarkan fakta-fakta dan pendekatan medis dan didukung oleh sains, sehingga informasi yang disampaikan bersifat teknis dan ilmiah. Remaja diberi materi tentang jenis-jenis penyakit yang menularkan infeksi lewat hubungan seksual, gejalanya, dan menyebutkan angka-angka statistik yang menggambarkan tingginya jumlah penderita.

Wacana kesehatan seksual dalam majalah Hai mendukung wacana seksualitas normatif. Ini ditunjukkan pada penekanan fungsi reproduktif seks yang menjelaskan seks dari sisi anatomi dan biologis. Perilaku seks bertujuan memperoleh keturunan, sehingga hanya dilakukan pasangan yang siap memiliki keturunan. Remaja dianggap belum siap karena harus menyelesaikan pendidikan. Salah satu akibat yang dijelaskan adalah perilaku seks berefek kehamilan yang tidak diinginkan:

Pertemuan sperma dan ovum (sel telur) akan membuahkan janin. Cewek hamil itu baru risiko secara fisik yang keliatan. Sementara cowok pasti kena efeknya. Kemungkinan yang terjadi adalah depresi alias secara psikis. Otak suntuk nggak karuan karena dituntut bertanggungjawab. Sementara niat belum pula siap untuk nikah. Belum lagi kalo ternyata pacar malah terganggu jiwanya gara-gara nggak kuat menghadapi kenyataan. Bisa jadi kemudian mengambil jalan pintas; aborsi atau bunuh diri sekalian. Di Jepang, seringkali ada kabar cewek bunuh diri gara-gara hamil (Bermain-main Dengan Resiko, 4/3/2002).

Kehamilan tidak diinginkan menjadi hambatan remaja untuk meneruskan pendidikan, sehingga akibat-akibatnya dijelaskan berdasarkan fakta-fakta biologis dan psikis. Selain menekankan efek perilaku seksual, pesan tersebut juga menyampaikan ancaman bahaya yang menimbulkan rasa takut. Misalnya artikel berikut ini menjelaskan fakta berdasarkan riset penderita HIV/AIDS disertai konsekuensi negatif seks bebas.

Dr Zubairi Djoerban Sp.PD, KHOM (Ketua dari Masyarakat Peduli AIDS Indonesia) membeberkan, bahwa di negara berkembang yang penduduknya banyak terjangkit HIV, sepertiga remajanya yang berusia 15 tahun akan meninggal karena AIDS. Di beberapa negara lain, seperti Zimbabwe justru lebih banyak lagi; 60 persen remajanya yang berusia 15 tahun akan meninggal karena AIDS. Baik di sana maupun di Indonesia, penyebaran HIV sebagian besar melalui hubungan seks. Meskipun akhir-akhir ini penularan HIV di kalangan pengguna drugs dengan jarum suntik meningkat cepat, penularan melalui hubungan seks masih jauh lebih banyak. (Kondom, Siapa Yang Butuh, 6/10/2000)

Pesan yang menggambarkan rasa takut akan akibat perilaku seksual ditampilkan lewat sosok setan atau tangan raksasa dalam ilustrasi artikel tentang penyakit yang diakibatkan oleh hubungan seksual yang tidak aman sebagai berikut: 


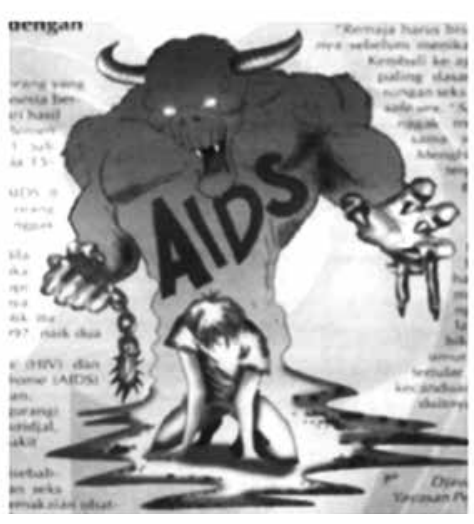

Gambar 1

Hai edisi 13/9/1999

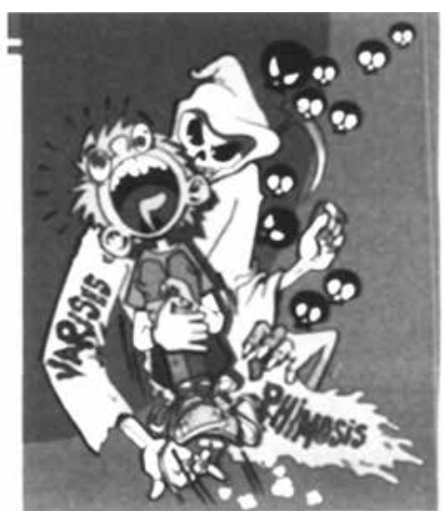

Gambar 2

Hai edisi 29/2/2002

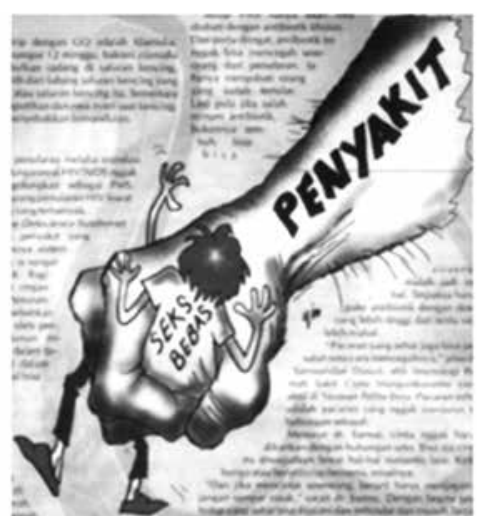

Gambar 3

Hai edisi 13/9/1999
Gambar 1 adalah ilustrasi artikel "HIV/ AIDS Mengincar Remaja!", menjelaskan mudahnya penyakit AIDS menular lewat cairan tubuh dan hubungan seks, bahkan hubungan non seksual. Penyakit ini sangat berbahaya dan belum ada obatnya. Kesan menakutkan ditampilkan lewat simbol setan. Pada gambar 2, setan menjadi simbol penyakit menular seksual yang mengancam remaja. Gambar 3 menunjukkan penyakit menular seksual membuat laki-laki tidak berdaya. Tangan raksasa dianalogikan penyakit yang mencengkeram laki-laki pelaku seks bebas.

Hal lain yang dijelaskan adalah penyimpangan seksual. Beberapa perilaku yang termasuk kategori menyimpang disebabkan oleh trauma masa lalu, dan disebut penyakit jiwa. Homoseksual, misalnya, selain persoalan psikologi yang didorong oleh faktor keluarga, dan lingkungan, klaim bahwa homoseksual merupakan penyimpangan seksual dan disebut sebagai orientasi seks yang kacau yang terjadi karena kelainan kromosom. Penjelasannya adalah:

"Ada dua jenis susunan kromosom yang normal. Di tubuh cewek susunannya XX. Sementara di cowok tuh XY. Kelainan terjadi bila di tubuh seseorang tuh susunan kromosomnya ketambahan satu unsur. Misalnya jadi XXY (di tubuh cewek) atau
XYX (di tubuh cowok). Kelainan susunan kromosom ini nih yang bikin seseorang punya kecenderungan tinggi jadi homoseks (lesbi buat cewek, dan gay buat cowok) (Penjelasan Dr. F. Loetan dalam Homoseksual Nggak Menular, 17/7/2004).”

Foucault menjelaskan bahwa seksualitas merupakan wacana yang dipahami sebagai efek relasi power atau knowledge (Hall, 2002:48-49). Pengetahuan diyakini sebagai kebenaran karena dilegitimasi oleh struktur kekuasaan. Untuk mendapat pengakuan atas kesahihannya, pengetahuan memerlukan kekuasaan, sementara kekuasaan membutuhkan sokongan pengetahuan untuk melanggengkan kuasanya. Saat inilah pendekatan sains memiliki kekuatan. Foucault menyebutnya scientia sexualis (1978:55), sebagai promosi seksualitas untuk tujuan reproduktif. Persoalan seks merupakan hal alamiah, berlangsung dalam perkawinan, dan tunduk pada heteronormativitas. Wacana seks bukan bertujuan untuk menyampaikan kebenaran tentang seks, namun untuk mencegah perilaku seks.

Menyampaikan bahaya seks secara menakutkan pada remaja adalah upaya pendekatan sains dan pengetahuan membangun pemahaman tentang seksualitas. Fakta-fakta biologis tentang seks disampaikan agar perilaku seks dihindari remaja. Hai tidak secara 
tegas melarang remaja melakukan aktivitas seks, tapi menganjurkan agar menghindarinya. Jika sudah telanjur, sebaiknya melakukannya dengan bertanggung-jawab. Hai menunjukkan bahaya seks tanpa melarangnya.

Menurut Oetomo dan Holzner (2004), perspektif sains berimplikasi pada wacana seks non-prohibitive dan bertujuan meningkatkan wawasan seksual remaja. Remaja berhak mengetahui proses fisik dalam tubuhnya dan pasangannya, remaja harus paham soal kesuburan dan kontrasepsi, dan bisa mencegah penyakit menular seksual. Untuk mencapai tujuan tersebut, persoalan nafsu, mimpi basah, ereksi dan ejakulasi, tubuh dan organ-organ seks dijelaskan untuk memenuhi hak remaja memahami tubuhnya. Misalnya tentang nafsu dalam tulisan "Gampang Horny!" (12/1/2004), Dr. F. Loetan menjelaskan alasan hormonal yang menyebabkan mudahnya lakilaki terangsang:

"Yap. Mulai umur 13 tahun hormon testosteron dalam tubuh kita tuh mulai aktif. Nah, nih hormon bikin organ reproduksi kita mulai bekerja maksimal. Mulai kenceng memproduksi sperma. Dan yang penting, bikin penis bisa berereksi penuh!. Dalam tulisan "Kenapa Cowok Gampang "Nyetrum"”'(24/1/1995), penjelasan biologis sebagai legitimasi tingginya libido laki-laki adalah hal normal dijelaskan Dr. G. Paat."

Nah, kapan "nyetrum" itu mulai datang? Jawabannya, saat kamu sudah akil baliq. Itu Iho, sudah dianggap sebagai laki-laki. Biasanya, ditandai dengan polusi malam (mimpi basah). Artinya, secara biologis kamu sudah memasuki masa kematangan seksual. Organ-organ seksnya udah bisa berfungsi penuh.

Pada topik mimpi basah, narasumber menjelaskan mimpi basah adalah hal alamiah dengan merujuk proses biologis yang terjadi. Misalnya berikut:

Kejadian ini berlatar belakang adanya perkembangan sel kelamin laki-laki yang sudah bisa digolongkan mencapai titik optimal. "Artinya, hormon testosteronnya sudah mencapai fungsi optimal," jelas Dr. Boy, sapaan akrab dokter kita itu. Hormon testosteron ini kan yang memproduksi sel-sel sperma di dalam testis. Itu semua merupakan suatu peristiwa alami yang normal (Wet Dream, Bukan Soal Porno Kok, 4/7/1995).

Di artikel tersebut juga dijelaskan istilahistilah kedokteran: nocturnal emission, istilah ilmiah mimpi basah, dan Vesicula seminalis atau kantong sperma, Selain itu, perhitungan matematis jadi pertimbangan, contohnya: "Menurut ilmu kedokteran, dalam satu hari hormon testosteron ini memproduksi tidak kurang dari 75 juta sperma. Nah, biasanya kantung sperma ini akan penuh setelah terisi sekitar 200 jutaan sperma. Alhasil, nggak heran ada orang mengalami wet dream tiga hari sekali"; atau hukum ilmiah seperti klaim berikut, "Yang benar adalah makin banyak seseorang beraktivitas, energi untuk pembentukan sperma akan berkurang, sehingga frekuensi wet dream berkurang." Rujukan ilmiah psikolog, sebagai berikut, "Memori bisa didapat dari penglihatan visual. Seperti nonton blue film, baca komik atau buku-buku porno, dan lain-Iain, tapi memori ini juga bisa tertransfer masuk karena pengalaman seharihari" (Hai, 18/3/2002).

Perilaku seksual juga dijelaskan lewat pendekatan ilmiah, misalnya mengapa ciuman menimbulkan nafsu, atau masturbasi sebagai perilaku normal (ini bertentangan 
dengan konsep masturbasi dalam perspektif agama yang juga diacu Hai seperti dijelaskan sebelumnya). Resiko perilaku tersebut dijelaskan beserta kasus-kasusnya. Penjelasan lengkap dari penyebab hingga akibat membantu remaja memutuskan apa yang dilakukan. Termasuk penggunaan kondom untuk mencegah akibat yang tidak diinginkan.

\section{Ambivalensi Wacana Seksualitas}

Majalah Hai membangun wacana seksualitas remaja laki-laki yang ambivalen. Ambivalensi wacana seksualitas yang terdapat dalam artikel dan rubrik seksualitas menjadi wujud akomodasi Hai atas berbagai wacana seksualitas, di antaranya paham konservatisme dan liberalisme seksual di Indonesia pada tahun 1990an dan 2000an.

Ambivalensi produksi wacana tersebut merupakan negosiasi dari diskursus tentang sakralisasi seks yang dibawa norma-norma sosial dan agama, gagasan revolusi seksual global, dan perspektif kesehatan reproduksi. Negosiasi diskursus-diskursus seksualitas merupakan strategi Hai untuk bertahan secara ekonomi, sosial, dan politik.

Bertahan secara ekonomi menjadikan konten seks sebagai komoditas yang potensial untuk dijual kepada pembaca dan pengiklan, juga sebagai akomodasi kepentingan generasi tua dan muda supaya Hai bisa diterima dan menjadi pilihan semua kalangan. Untuk remaja sebagai target pasar yang identik dengan generasi anti kemapanan, hedonis dan konsumtif, Hai mempromosikan gagasan tentang kebebasan seksual. Sementara dalam menghindari konflik dengan orang tua sebagai pihak pembeli (mahasiswa belum mampu membeli majalah dengan uang mereka sendiri)
Hai memilih untuk tetap mempertahankan nilai-nilai normatif. Wacana seksualitas dalam majalah Hai adalah jalan tengah di antara dua wacana yang dominan tersebut. Upaya ini tidak lain adalah strategi Hai untuk mempertahankan pangsa pasarnya.

Bertahan secara sosial berarti eksistensi Hai tidak menimbulkan polemik di masyarakat. Wacana kebebasan seksual belum bisa diterima oleh pihak tertentu, misalnya kelompok agama, terutama Islam yang pengaruhnya cukup kuat pada tahun 1990an dan 2000an. Namun, di sisi lain wacana ini juga digaungkan oleh kelompok masyarakat lainnya, misalnya kelompok feminis dan pembela hak asasi manusia. Ambivalensi yang terjadi merupakan upaya Hai untuk menjembatani kepentingan-kepentingan tersebut.

Bertahan secara politik artinya tidak berkonflik dengan pemerintah. Kondisi ini menggambarkan kompromi Hai dan kepentingan pemerintah lewat penyampaian informasi tentang seks dan seksualitas yang sejalan dengan kepentingan pemerintah.

Model jalan tengah dalam membangun wacana seksualitas merupakan politik dua kaki Hai untuk mengakomodasi kepentingankepentingan yang mempengaruhi eksistensinya dalam bisnis media cetak yang dijalankan oleh PT Kompas Gramedia. Strategi mengakomodasi berbagai kepentingan ini menjadi andalan Jacob Oetama untuk mempertahankan Kompas sehingga mampu menjadi surat kabar yang terkemuka. Pengalaman Kompas saat mengalami dua kali pembredelan tahun 1965 dan 1978 mendorong Kompas untuk menerapkan prinsip hati-hati dalam menyiasati berbagai kondisi sehingga mampu 
bertahan hidup. Tidak mengherankan jika Hai juga berada di bawah kendali Jacob Oetama. Irwan Iskandar-mantan pemimpin redaksi majalah Hai-mengatakan bahwa ia lebih takut pada Jacob Oetama daripada Harmoko selaku menteri Penerangan saat itu yang berwenang pada urusan SIUPP (wawancara, 9 Januari 2014).

Belajar dari kasus Kompas dan mediamedia lain di bawah bendera PT Kompas Gramedia, maka politik Hai mengikuti politik bermedia yang dijalankan Jacob Oetama yang menghindari konflik dengan pemerintah. Dalam menampilkan konten seksualitas, Hai mengikuti pedoman yang digariskan oleh pemerintah. Salah satunya adalah menghindari unsur-unsur pornografi. Adanya standar pornografi yang ditetapkan oleh pemerintah mendorong Hai menghindari unsur pornografi dalam konten seks dan seksualitas. Seksualitas identik dengan pornografi. Untuk itu Hai menyiasatinya lewat ilustrasi kartun yang menggambarkan orang berciuman atau tubuh telanjang, dengan muatan humor. Selain menggunakan gambar kartun, Hai juga memanfaatkan gambar-gambar tertentu untuk mengilustrasikan objek-objek yang mengandung unsur pornografi, seperti alat kelamin sebagai personifikasi.

Dalam tulisannya tentang PT Kompas Gramedia, Hill (2011:101) menegaskan bahwa kelompok Kompas Gramedia adalah satu-satunya media yang paling siap menghadapi batasan-batasan yang ditetapkan pemerintah. Jacob Oetama bertindak tegas pada media-media di bawah kendalinya, dengan mendisiplinkan jurnalisnya atau menutup medianya daripada mengambil resiko berhadap-hadapan dengan pemerintah dan reaksi masyarakat. Kompas menjaga agar tulisan-tulisannya tidak melampaui batas. Politik "main aman" yang dijalankan Jacob Oetama inilah yang diadopsi majalah Hai ketika mendiskusikan seksualitas.

\section{Simpulan}

Wacana seksualitas yang dibangun majalah Hai merupakan bentuk negosiasi atas berbagai kepentingan. Wacana seksualitas tersebut merupakan implikasi politik bermedia majalah Hai dengan merangkul berbagai kepentingan pihak yang mempengaruhi eksistensi majalah Hai dalam industri media cetak di Indonesia. Ambivalensi wacana merupakan jalan tengah atau negosiasi yang dilakukan majalah Hai di antara berbagai kepentingan tersebut.

Artikel ini tidak terlepas dari keterbatasanketerbatasan tentang hal-hal penting yang belum dieksplorasi lebih lanjut. Pendekatan ekonomi politik belum tereksplorasi secara mendalam. Persoalan seks dalam majalah Hai yang ditelaah secara khusus lewat pendekatan ekonomi politik menjadi tema yang perlu dipertimbangkan.

Fokus pada teks dan produksi teks di tulisan ini belum melibatkan pemaknaan dari pembaca. Untuk itu, penelitian-penelitian yang melibatkan khalayak sebagai target teks bertema seksualitas juga menarik dilakukan. Penelitian khalayak sasaran kegiatan pendidikan seks layak dipertimbangkan pada artikel berikutnya untuk dapat memahami bagaimana produksi wacana oleh khalayak atas teks-teks bertema seksualitas. 
Hal-hal yang berkaitan dengan sumber teks juga berpotensi untuk dieksplorasi lebih lanjut. Produser teks yang saling berdebat memenangkan kepentingannya di newsroom akan menggambarkan bagaimana dinamika sebuah teks. Teks diproduksi melewati serangkaian proses pertarungan wacana yang dibawa oleh pihak-pihak di belakang "layar". Hal-hal tersebut perlu menjadi perhatian pada penelitian-penelitian wacana seksualitas remaja laki-laki di masa mendatang. Walaupun majalah Hai kini telah berubah format penerbitan secara online, menurut penulis hal-hal tersebut masih berpotensi untuk dilakukan.

\section{Daftar Pustaka}

Alimi, MY. (2004). Dekonstruksi Seksualitas Poskolonial: Dari Wacana Bangsa Hingga Wacana Agama, Yogyakarta: LKIS

Allen, L. (2011). Young People and Sexuality Education: Rethinking Key Debates, New York: Palgrave Macmillan

Baulch, E. (2002). Alternative music and mediation in Late New Order Indonesia, Inter-Asia Cultural Studies, 3(2)

Blackwood, E. (2005). Transnational Sexualities in One Place: Indonesian Readings, Gender and Society, 19(2) Sexuality in Indonesian Discourse: Normative Gender, Criminal Law, and Shifting Strategies of Control, Culture, Health and Sexuality, 9(3)

Escoffier, J. (2015). The Sexual Revolution 19601980 dalam http://www.glbtqarchive.com/ ssh/sexualrevolution_S.pdf, diakses 14 Februari 2016

Fairclough, N. (2000). Critical Analysis of Media Discourse. Dalam P. Marris dan S. Thornham, Media Studies: A Reader, 2nd ed., New York: New York University Press
Fischer, N. (2005). "Purity and pollution: sex as amoral discourse". Dalam S. Seidman, N. Fisher, dan C. Meeks, Handbook of The New Sexuality Studies, London dan New York: Routledge

Foucault, M. (1978). The History of Sexuality, Vol. 1, New York: Pantheon Books

Giddens, A. (1991). Modernity and Self Identity: Self and Society in the Late Modern Age, California: Stanford University Press

(1992). The Transformation of Intimacy: Sexuality, Love, and Eroticism in Modern Society, California: Stanford University Press

Giroux, HA. (1998). "Teenage Sexuality, Body Politics and the Pedagogy of Display". Dalam J. Epstein, Youth Culture: Identity in a Postmodern World, Oxford: Blackwell

Hall, S. (1997). "The Work Of Representation”.

Dalam Stuart Hall, Representation: Cultural Representations and Signifying Practices, London: Sage Publication

Handajani, S. (2010). Selling Alternative Masculinities: Representations Masculinitiens in Indonesian Men's Lifestyle Magazines, $\mathrm{PhD}$ Thesis, The University of Western Australia

Hekma, G. dan Giami, A. (2014). "Sexual Revolution: An Introduction". Dalam Gert Hekma dan Alain Giami, Sexual Revolutions, New York: Palgrave Macmillan

Hill, David T. (2011). Pers Di Masa Orde Baru, Jakarta: Yayasan Pustaka Obor Indonesia

Jackson, S. (2006). Gender, Sexuality and Heterosexuality: The Complexity (and Limits) of Heteronormativity, Feminist Theory, 7(1)

Kimmel, MK. (2005). Gender of Desire: Essays on Male Sexuality, Albany: State University of New York Press 
Nilan, P. (2006). "The Reflexive Youth Culture of Devout Muslim Youth in Indonesia". Dalam P. Nilan dan C Feixa. Global Youth? Hybrid Identity, Plural Worlds (h. 91-110). New York: Routledge dan Holzner, B. (2004). Youth, Sexuality and Sex Education Messages in Indonesia: Issues of Desire and Control, Reproductive Health Matters, 12(23)

Parker, Lyn. dan Nilan, P. (2013). Adolescents in Contemporary Indonesia, New York: Routledge

Pearson, JC, West, R. dan Turner, L. (1995). Gender and Communication, USA: McGraw Hill

Plummer, K. (2005). "Male Sexualities". Dalam MK Kimmel, J. Hearn, dan RW Connel, Handbook of Studies on Men and Masculinities, California: Sage Publications

Schmidt, L. (2012). Post Suharto Screens: Gender, Politics, Islam, and Discourses of Modernity, Amsterdam SocialMScience, $4(1)$
Sen, K. (1998). "Menafsirkan Feminisme Dalam Sinema Orde Baru: Represi dan Resistensi". Dalam Idi S. Ibrahim dan H. Suranto, Wanita dan Media: Konstruksi Ideologi Gender dalam Ruang Publi Orde Baru, Bandung : Remaja Rosdakarya

Suryakusuma, Julia. (1998). "Beban Muskil Majalah Wanita”. Dalam Idi S. Ibrahim dan H. Suranto, Wanita dan Media : Konstruksi Ideologi Gender dalam Ruang Publik Orde Baru, Bandung : Remaja Rosdakarya . (2011). State Ibuism: The Social Construction of Woman hood in New Order Indonesia, Jakarta: Komunitas Bambu

Wieringa, SE. (2003). The Birth of The New Order State in Indonesia: Social Politics and Nationalism, Journal of Women History, 15(1) 